\title{
万国共通番手“tex”について
}

東京工業大学 由樫㑆

この番手方式はあらゆる種類の㵶維および瀻維製品に 対し，万国共通の唯一つの番手方式として用いるものと Lて, 国際標準化機構 (International Organization for Standardization, 略称 ISO) 専門委員会が決議したも のであつて，轪維製品の線密度を重量をグラムで，舆さ をメートルで現わすとするものである。
すなわも基本単位としてキロメートル女たりのグラム

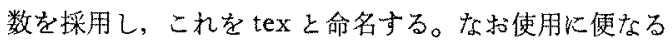
ためつぎの単位をきめる。

キロメートルおたりミリグラム $(\mathrm{mg} / \mathrm{km})$ で表わし Millitex (mtx) と呼岕。

メートルあたりダラム $(\mathrm{g} / \mathrm{m})$ t支 tex, キロメートル あたりキログラム $(\mathrm{kg} / \mathrm{km})$ を Kilotex 1. 愃 重 式

第 1 表 tex 番手方式の換算

\begin{tabular}{|c|c|c|c|c|c|}
\hline \multirow{2}{*}{$\begin{array}{l}\text { 現行采番手 } \\
\text { 方式の記号 }\end{array}$} & \multirow{2}{*}{$\begin{array}{l}\text { 糸番手方式の } \\
\text { 名 称 }\end{array}$} & \multirow{2}{*}{ 適 } & \multirow{2}{*}{$\begin{array}{l}\text { 琴行亲番乎 } \\
\text { 方式の単位 }\end{array}$} & \multirow{2}{*}{ 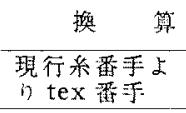 } & \multirow{2}{*}{$\begin{array}{l}\text { 公 式 } \\
\text { tex 番手より現 } \\
\text { 行系㮰 }\end{array}$} \\
\hline & & & & & \\
\hline $\mathrm{Nm}$ & メートル式 & 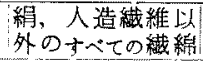 & $1000 \mathrm{~m} / 1000 \mathrm{~g}$ & $1000 / \mathrm{Nm}$ & 1000/tex 香 \\
\hline $\mathrm{Nf}$ & 式 & 緛 系 & $1000 \mathrm{~m} / 500 \mathrm{~g}$ & $500 / \mathrm{Nf}$ & $500 /$ tex 举手 \\
\hline $\mathrm{NeC}$ & 式(綿) & 綿系，綟紡系 & $840 \mathrm{Y} d / 1 \mathrm{~b}$ & $590,541 / \mathrm{NeC}$ & $590,541 /$ tex \\
\hline $\mathrm{NeL}$ & $\begin{array}{l}\text { 英式 业 麻 } \\
\text { cut }\end{array}$ & $\begin{array}{l}\text { 垔 淋(湿式) } \\
\text { 系 }\end{array}$ & $300 \mathrm{Yd} / \mathrm{lb}$ & $1653,52 / \mathrm{NeL}$ & $1653,52 /$ tex番手 \\
\hline $\mathrm{Ne}$ & 英式梳专 & 梳 毛 & $560 \mathrm{Yd} / \mathrm{lb}$ & $885,812 / \mathrm{Ne}$ & 885,812 /tex番手 \\
\hline $\mathrm{NeW}$ & $\begin{array}{l}\text { 英式毛系 } \\
(\Xi-B シ+)\end{array}$ & 系 & $\begin{array}{l}256 \mathrm{Yd} / \mathrm{lb} \\
(=\mathrm{Yd} / \mathrm{dram})\end{array}$ & $1937,71 / \mathrm{NeW}$ & 番手 \\
\hline $\mathrm{Nt}$ & type & 毛 & $1000 \mathrm{Yd} / \mathrm{lb}$ & $496.1 / \mathrm{Nt}$ & 496.1/tex番手 \\
\hline $\mathrm{Na}$ & allon & 毛 & $1152 \mathrm{Yd} / \mathrm{lb}$ & $1033.4 / \mathrm{Na}$ & 1033.4/tex番手 \\
\hline $\mathrm{Ng}$ & calashielf & 毛 & $300 \mathrm{Yd} / 240 \mathrm{z}$ & $2480.3 / \mathrm{Ng}$ & $2480.3 /$ tex 番乎 \\
\hline $\mathrm{Nh}$ & Hawick & 毛 & $300 \mathrm{Yd} / 260 \mathrm{z}$ & $2687 / \mathrm{Nn}$ & $2687 / \mathrm{tex}$ 番手 \\
\hline NWe & $\begin{array}{l}\text { Western } \\
\text { England }\end{array}$ & 紡毛 & $320 \mathrm{Yd} / \mathrm{lb}$ & $1550.2 / \mathrm{NWe}$ & $1550.2 /$ tex 番 \\
\hline $\mathrm{N}$ & & 毛 & 160 & $310.0 / \mathrm{N}$ & 潘乎 \\
\hline Naw & $\begin{array}{l}\text { American } \\
\text { Wool number }\end{array}$ & 紡 毛 & $100 \mathrm{Yd} / 0 \mathrm{z}$ & $31.00 / \mathrm{Naw}$ & 31.00 /tex番手 \\
\hline $\mathrm{Nd}$ & $\begin{array}{l}\text { Dewsbury (デ } \\
z ー ス ヘ ゚ y ー) ~\end{array}$ & 紡毛 & $\mathrm{Yd} / \mathrm{oz}$ & $31.00 / \mathrm{N}$ & $31.00 /$ tex 番手 \\
\hline $\mathrm{Na}_{\mathrm{A}}$ & $\begin{array}{l}\text { American } \\
\text { asbest 及び英 } \\
\text { * glase }\end{array}$ & asbest glase & $100 \mathrm{Yd} / 1 \mathrm{~b}$ & $4961 / \mathrm{Na}_{\mathrm{A}}$ & .4961/tex 僠手 \\
\hline$N C_{C}$ & Catalonian 綿 & 綿 & $\begin{array}{r}500 \mathrm{Can} \\
\text { Ilib }\end{array}$ & $565.92 / \mathrm{NcC}$ & 565.92/tex 番乎 \\
\hline $\mathrm{Np}_{\mathrm{p}}$ & puntos number & & $\begin{array}{l}1320 \mathrm{~m} / 1 \text { libra } \\
\text { of Alcoy }\end{array}$ & $356.71 / \mathrm{Np}$ & 358.71/tex 番手 \\
\hline $\mathrm{Niw}$ & $\begin{array}{l}\text { アイルランド } \\
\text { 毛 }\end{array}$ & 毛 & $\mathrm{Yd} / 0.250 \mathrm{z}$ & $7750.8 / \mathrm{Niw}$ & 7750.8/tex莉手 \\
\hline
\end{tabular}

2. 恒 重 式

\begin{tabular}{|c|c|c|c|c|c|}
\hline \multirow{2}{*}{$\begin{array}{l}\text { 覟行系番手 } \\
\text { 方式の記号 }\end{array}$} & \multirow{2}{*}{$\begin{array}{l}\text { 等手方式の } \\
\text { 名 称 }\end{array}$} & \multirow[b]{2}{*}{ 獣 } & \multirow{2}{*}{$\begin{array}{l}\text { 琴行采番手 } \\
\text { 方式の単位 }\end{array}$} & 算 & 公 \\
\hline & & & & $\begin{array}{c}\text { 現行系番手上 } \\
b \text { tex 笛 }\end{array}$ & $\begin{array}{l}\text { tex 番上り現 } \\
\text { 行系番 }\end{array}$ \\
\hline $\mathrm{Td}$ & 正統タイター & 絹，人造繊維 & $\mathrm{g} / 1000 \mathrm{~m}$ & $0.111111 \mathrm{Td}$ & $9 /$ tex 番手 \\
\hline Ts & $\begin{array}{l}\text { スコットラン } \\
\text { ドイター }\end{array}$ & $\begin{array}{l}\text { 亜床(乾紡) } \\
\text { 大麻及び黄麻 }\end{array}$ & $\begin{array}{c}\mathrm{Ib} / 14400 \mathrm{Yd} \\
\text { (㴍洋位) }\end{array}$ & $34,4482 \mathrm{Ts}$ & $\begin{array}{r}0.0290291 / \\
\text { tex 潘手 }\end{array}$ \\
\hline $\mathrm{Ta}=\mathrm{Ts}$ & Aberdeen & 紗 毛 & $\mathrm{lb} / 14400 \mathrm{Yd}$ & $34.4482 \mathrm{Ts}$ & |0.0290291 tex 番手 \\
\hline $\mathrm{Tp}$ & Poumar & & $\mathrm{lb} / 1000000 \mathrm{Yd}$ & $0.496 \mathrm{Tp}$ & 2.0161 tex 番手 \\
\hline Ts & 絧 & & $\mathrm{dram} / 1000 \mathrm{Yd}$ & $1.938 \mathrm{Ts}$ & 0.51599 tex 番手 \\
\hline $\mathrm{TaG}$ & $\begin{array}{l}\text { *⿻丷木大式 grain } \\
(ヶ v-v)\end{array}$ & 紡 & grain $/ 20 \mathrm{Yd}$ & $3.543 \mathrm{Tag}$ & 0.28225 tex番手 \\
\hline $\mathrm{Nb}$ & $1 / 4 \mathrm{oz}$ 式 & & $1 / 40 z / 500$ canvas & $10.714 \mathrm{Nb}$ & 0.0933 tex 番手 \\
\hline $\mathrm{Ncw}$ & $\begin{array}{l}\text { catalonie } \\
\text { 䏻毛糸スター }\end{array}$ & 紡 & $\mathrm{g} / 504 \mathrm{~m}$ & 1. $9841 \mathrm{New}$ & 0.504tex番手 \\
\hline
\end{tabular}

(ktx) と呼ぶ。

この共通番手方式 を“tex 式”と呼占 ことにする。

系番手の記载方法 は最初塑位すなわ方 tex とかき，つぎに 数值を記载すること が望ましい。例点ば 単采では tex 30 , 諸 系では tex $30 \times 2$, a ートでは tex $\times 27 \times$ $5 \times 3$ の上5にする。 (tex $30 / 2$, tex $27 / 5 / 3$ の上らな記載ですよ いであら5)

現行䒺番手方式を tex 方式化控算する ためには第1表に示 した換算武を用いる ことが望ましい。

現行手番手を tex 番手に換算するばあ い, 多くのばあい小 数位の数值がつく㫗 のであるが，实用上 は通例概算数值が与 无られるであるらか

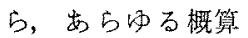
tex 番手に効して第 2 表に示すよ $5 な 2$ れそれの精確值の籁 因が定められてある。 
第 2 瑟

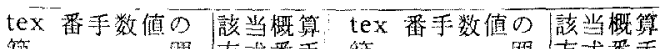

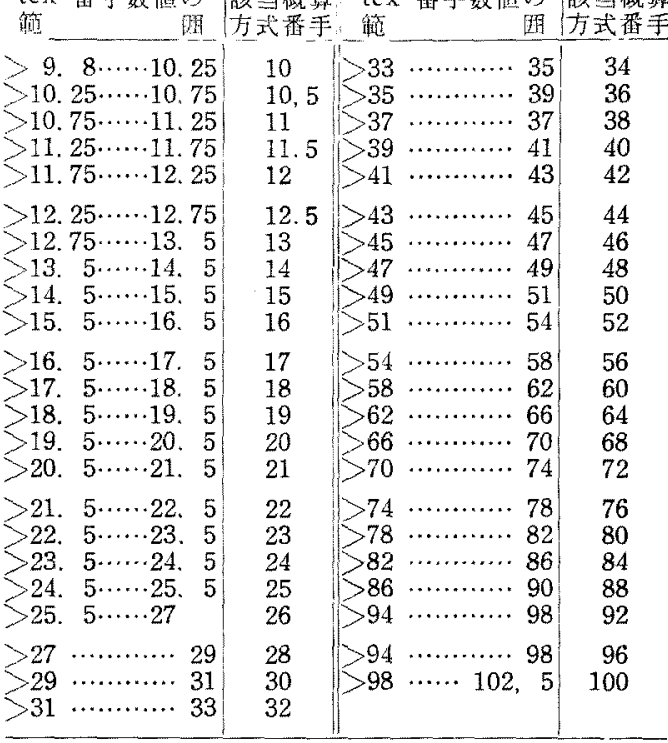

この方式はデニール式と同栐に糸の直径が增大するに つれて，大きくなるといつた面接法（いわ怔る恒長式番 手法）でって，実用単位としては系については tex， 䄉維には millitex (mtx)，コードとかスライパには kilotex (ktx) を用いるのが便利である5。

さてこのよ5な万国共诵番手方式をあらゆる種類の䋐 維の系についてすへていの繊維閔係分野で使用するとした ISO 㵶維莗門委員会（ISO/TC 28）の浃議はきわめて重

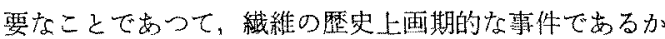

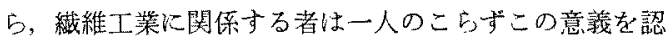
識する必要が古る。

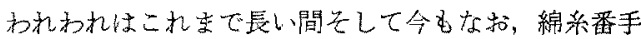
方式，毛采番手力式，麻系番手方式とか編系番手方式な ビのはん蓶さによ゙れくらい手数学か外，混乱をきたして いるか、はかり知ることができないであるう。1873年の

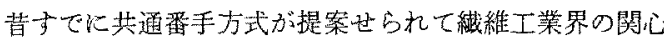
の的となつていたにもかかわら寸゙，今日までその实現を

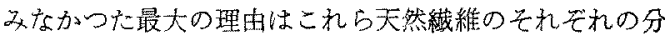
野で発生した歷史的留慣と，これらの天然䋞維が単独に いずれも大きな瀻維工業としての立場を確立していたこ とによるすのであろう。

しかしながら最近の㵶雜工等の発展は，一つの工場で 翻手方式の異なる各種の系を取あつからことや，綿や羊 毛と化繊や合成瀻維を混合して一つの䋐維だけからは決 して得られない特質を発揮せしめるというようなことは 全く当然のことがらとなつてきた。ここに其通番手方式 を使用することの必要性がきわめ大きくなつてきたの
であるが，さらに䋐維分野の研究者は緎維の種類に閣保 なく，番手による䄉度，強力，その他諸性質を現わす簡 単な方法を求めて招り，共通番手力式を採用すれば，各 種䋐維をあつから研究もすへて統一ができるのである。

すなわすこの万国共通番手方式を完全に実施できるな

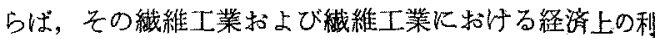
益と研究や技術上の利点はまことに多大なるのが期待さ 孔 5 。

例竟ば

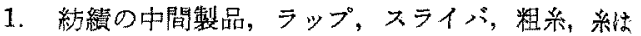

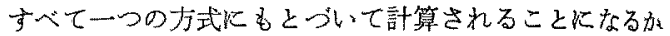
ら，ドラフトなどの紡績計算がきわわて容易になる。

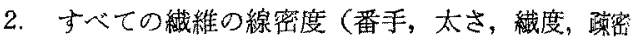
度)が同じ単位で現わされるから，各繊維について涀台 や縕維特性の矯正が容易にできる。

3. 維の種類にかかからず，すべての系の線密度が 同じ単位で現わされ换算の必要がない。また1本1本の 糸の大きさが異なるばあいの撚糸の計算も，容昒にでき る。

4. 系は瀻維によらず同じ単位であるから、織物原単 位の計算などはすべて簡単になる。

5. 破断強力, 番手強力積，切断長の上5な系特性む すへての糸に同じ単位で現わされる。(破断強力 $\mathrm{g} / \mathrm{tex}$ キロメータで現わされた破断長住しくなる。

この万国共通番手方式に切りかえたばあい，一時的

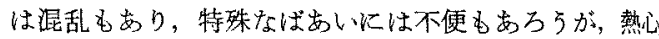
な努力が重权られればこれらの長所は立派に役立つてく ることがかかるであらう。現にこの万国共通番手方式を 数年間にわたつて実施してきている工場では，いずれる 例外なしにこれらの工堨が促来の番手方式を採用してい る国にあつて孤立したよ5な立場に立つていても，この tex 方式の採用がひじょうに有效で渾足す心゙きのであ ると報告している。

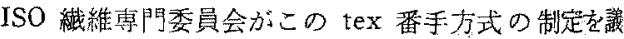
決なるに至るまでにはき㧅めて慎重な調查と長い期間の

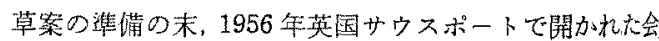
合で万場一致でこれを推葶することに決めたものであり

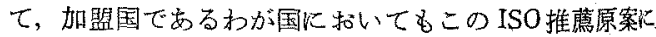
対 L, 工策技術院標準部緎維部会に执いて槙重塪議の絡 果, 昭和 33 年 5 月賛成を回答した。

ISO 専門委員会は従来の番手方式加らこのtex 番手方 式に移行するための指導にはむる程度の期間を必要とす るとして，つぎの 3 段階によることを萑めている。

第 1 段階：現行番手方式は引つつき整らくの間使用す るが，ての采手の後にカッコを用いて tex 番手を添記 する。例えばメートル式番手 Nm 17 (tex 60) とする。 
第 2 段階：較造は tex 番手方式に変更し，取引上では tex 番手の後にカッコを用いて現行系番手を添記する。 例えば tex 32 (綿番手 $\mathrm{NeC} \mathrm{18,45)， \& たは} \mathrm{tex} 80$ (英 武气毛番手 $\mathrm{Ne} \mathrm{11.07)} \mathrm{とする。}$

第3段階：カッコ内の表示索抹消する。 というきわめて慎重なすすめ方を準備しているのである が，すでにメートル法の寒施に入つているわが国化り てはこの tex 方式の採用はむし万他に率先して合理的に 推進され れるすのと考光る。
それは世界の主要䋐維工業国を代表する人達の絸心な

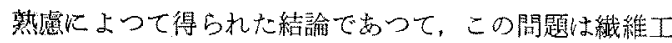
業に従事している人達と，その工業の発展を頴つている すべての人迹によつて育てられ笑現されるものであるか ら，この tex 番乎方式をき的めて強力に推准し上うと試

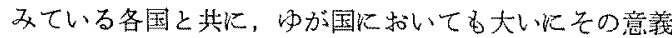
を認識して普及をはかりたいものと切望するしだいで女 范。

(昭和 33 年 12 月 22 日受理)

\section{未発表の粘弾性的研究の二, 三を中心として（追記）}

一般に緩和スペタトルより高分子物筫の粘度 (tensile viscosity) $\eta$ を求める主な力法は下記の如くである。

$$
\begin{aligned}
& \eta=\int_{-\infty}^{\infty} H(\ln t) \tau d(\ln \tau) \text { (従来の方法) (1) } \\
& \eta=\int_{-\infty}^{\infty} E r(t) t d(\ln t) \quad \text { (Fujita の方法) (2) } \\
& \eta=\sum_{i=a}^{m} E i(\tau) \tau i(\text { Tobolsky-Murakami の方法 (3) }
\end{aligned}
$$

但し $t ， \tau$ はそれぞれ観䁚時間，緩和時間，更に $H(\ln \tau)$, $E i(\tau)$ は和時間分有函数， $E r(t)$ はナング率である。 既報 (昭和 33 年 12 月号轼維学会誌資料) 交中に沶 いて藤田氏が筆者あて私信をよこされ， polydisperse ならびに monodisperse 兩ポリスチロールの緩和スペク トル図において，彼が（1）式により計算した両者の値 の比が分子量 $M w$ の比に比べて大きすぎることの原因 北関して問合せがあつたことを述べたが，ての後研究の 結果われわれの結論が一致したのでここに追記する。

筆者らはその後各種の monodisperse, polydisperse のポりスチロール試料を使用して，それらの緩和スべク

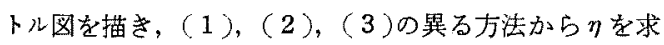
わた結果, polydisperse の場合は 3 者とも一致した結果 をらるが, monodisperse 試料においては，(1)の方法

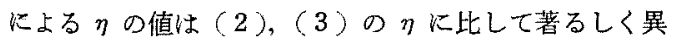
り, その差異は明らかに $M w / M n$ 值に影響されて, monodisperse 度の著るしい試料仕ど大きな差がえられて いる。つまり楥和スペクトル図から $\eta$ を求める場合は,

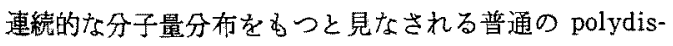
perse 試料の場合は，従来の方法 (1)でよいが, monodisperse 試料になると，もはや彷来の(1) 式の成立は
在プッンストン大学 村上謙吉

因難となる。それ故藤田氏はこの(1)式を使用して polydisperse, monodisperse 両試料の $\eta$ 計算し, 両者 の比較をされたところに不当な差が出る原因が生じた。 かかる筆者の意見を Prof. Tobolsky b認めたので、藤 田氏に早速缻返事したところ，同氏より次の如き書信を いただいた。以下原文のまま。

村上学兄

われわれの $\eta$ の式 (2)を使つて計算された結果が多 当な範四に括ちたと聞いて喜んでいすす。前にも書きま したように $\operatorname{Er}(t)$ 曲線のゴム状 $\rightarrow$ 夜状転移領域のとこ ろのHを出すのは現在のどの近似方法を使つてす無理な ように思います。それを示すよい例を近く出る高分子実 戨諈坐の粘弾性の巻に小生が記しておき括したので御参 考下さると羍いです。しかし大兄らがやられたよにに monodisperse 試料を取扱 5 時は，この領域の $H$, つ李 り絶壁のように切り立つたHを閏題にしなければならな いのですからこのまたりのHをむつと正確に求める近 似方法を見つけることは一つの面白い問題で患ると思い ます大兄らが(1)式の代りに( 3 )式老使市れたのもこ れに対する一つの策であると思います。

小生も京大農学部水産学科の物理化学研究空でポリマ 一の仕乑を始めてからまだ数年にしかなりませんが，幸 い上い若い研究者を幾人か持ちえたこと，また数年前に オランダ，アメリカとわたり歩いたことによつて，いく

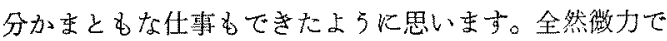
すが今後とも学兄らとともに日本の高分子研究のレベル を少しでも引上げることができれは塟いる思つていま के。

藤田博 